\title{
Legal aspects of a healthy diet for children. Comments on the grounds of the directive on foodstuffs in schools
}

\author{
Monika Urbaniak \\ Faculty of Health Sciences, Department of Medical Law, Poznan University of Medical Sciences, Poland
}

\begin{abstract}
The aim of this article is to analyze legal solutions for the availability of foodstuffs in schools, binding from Sep 1, 2015, targeted to introduce into school shops and canteens so-called healthy food. The Directive issued by the Minister of Health on Aug 26, 2015 on groups of foodstuffs intended to be sold to children and young people in education system units and requirements for foodstuffs used within collective feeding of children and young people in those units eliminated from school shops provide a list of food which is considered unhealthy. The adopted solutions are an introduction to the legal statutory fight against obesity in children and young people and enhance the protection of the health of children at pre-school and school age by limiting access within kindergartens, schools and tutelary-educational institutions to foodstuffs containing significant quantities of ingredients not recommended for their development.
\end{abstract}

Keywords: food, obesity, liberty of economic activity, children and young people.

\section{Introduction}

The aim of this article is to analyze legal solutions for the availability of foodstuffs in schools, binding from Sep 1, 2015. These new solutions are intended to introduce into trade in school shops and canteens so called healthy food. Like any revolutionary changes, they generate a series of questions regarding their conformity with the Polish Constitution [1] and also contribute to the discussion on overall solutions intended to fight against obesity in children and young people in a broader perspective. The new regulations are protested against by entrepreneurs who run businesses in schools as they state that the list of products approved for sale is too restrictive, due to the fact that it eliminates from students' diets products containing too much sugar. They also point out that students will continue to provide themselves with so called junk food due to the proximity of regular groceries to schools or due to a lack of changes in nutritional habits at home which results in bringing unhealthy food to school.
The Directive issued by the Minister of Health on Aug 26, 2015 on groups of foodstuffs intended to be sold to children and young people in education system units and requirements for foodstuffs used within collective feeding of children and young people in those units [2], which entered into force on Sep 1, 2015 , eliminated from school shops food which is considered unhealthy. It needs to be pointed out that the Directive was published in the Journal of Laws of Aug 28, 2015 i.e. three days before it entered into force. The entrepreneurs point out that such a short period of vacatio legis makes it difficult for the addressees of those provisions to adapt to the new legal conditions. The Constitutional Tribunal in its judgment of March 2, 1993 [3] emphasized that "the principle of the rule of law requires that a modification of law binding so far which implies unfavorable effects for the legal situation of entities be in principle introduced under the regime of interim provisions or at least with a proper vacatio legis as they let the entities involved adapt to the new 
legal conditions. The legislator may abandon them and decide to introduce directly (immediately) a new law - if to do so is justified by an important public interest which cannot be outweighed by the interest of an individual". In this case, although the modification of binding legal provisions had unfavorable effects on businesses such as school shops, the legislator decided not to extend the period which would allow them to adapt to the new legal situation. Pursuant to the provisions of Article 2 of the Act of Nov 28, 2014 on the modification of the Act on food and feeding safety [4], the date of entering into force of Article 52c, which is the basis to issue the Directive in discussion was determined to be Sep 1, 2015. Considering the necessity to adapt by businesses to the new legal situation, the legislator passed a relatively long period of vacatio legis. However, there is still a question about the lawfulness of the basis of the Directive issued. If the Act of Nov 28, 2014 on the modification of the Act on food and feeding safety determined the date of its entrance into force to be Sep 1, 2015 and the Directive of the Minister of Health was issued on Aug 26, 2015 pursuant to Article $52 \mathrm{c}$ of the Act on food and feeding safety, this means that it was issued on the basis of an act which had not yet entered into force. Under $\S 127$ of legal technicality [5] a directive should enter into force on the date of entrance into force of the act being the basis for the issuance of the directive. Also, under $\S 128$, section 1 of the legal technicality a directive may be issued after the act containing a provision which authorizes its issuance is published and before the act enters into force. In such a ase, the date of entrance into force of a directive is determined as a date no sooner than the date of entrance into force of the act that authorizes the issuance of such a directive. Considering the above, it needs to be stated that the directive in discussion conforms with legal technicality. The rules of legislation proceeding provided for in the act are directly binding for the government legislator [6]. Moreover, Article 7 of the Act of July 20, 2000 on the publication of normative deeds and some other legal deeds [7] clearly states that normative deeds issued on the basis of acts may be published within the period between the date of the publication of the act and the date of its entrance into force; such a deed may not enter into force before the act.

Considering the fact that directives are issued on the basis of acts and in order to execute them and their most important function is to enable the execution of the provisions of the act, it is obvious that the executory provisions should enter into force together with the new basic provisions [8]. Furthermore, it needs to be remembered that under $\S 13$ of the legal technicality, together with a draft version of an act, the draft directives which are fundamental for its execution are drawn up. The Directive under discussion undoubtedly is a deed on which the execution of the provisions of the act depends. The Constitution in Article 92 section 2 provides that directives are issued by authorities specified in the Constitution on the basis of a detailed authorization contained in the act for the purpose of its execution. The authorization should specify the authority competent to issue the directive and the scope of matters to be regulated and guidelines regarding the content of the deed. This provision results in the fact that the lawfulness of a directive depends on the accomplishment of the constitutional grounds for its issuance. In the case of the Directive of the Minister of Health of Aug 26, 2015 on groups of foodstuffs intended to be sold to children and young people in education system units and requirements for foodstuffs used in the collective feeding of children and young people in those units, it needs to be said that the statutory authorization was complete as it specified the authority competent to issue it and specified in detail the scope of the matters to be regulated.

Pursuant to the content of $\S 1$ of the aforementioned directive, it specifies groups of foodstuffs intended to be sold to children and young people in education system units. In practice this means that the foodstuffs enlisted in Schedule 1 of the directive cannot be sold in school shops, canteens or vending machines. Moreover, the directive sets forth the requirements for foodstuffs used in the collective feeding of children and young people in education system units. These requirements result from the principles of a rational diet in collective feeding and are based on norms for feeding children and young people and the nutritional and health values of the different foodstuffs.

The adopted solutions are intended, according to the grounds of the draft directive, to enhance the protection of health in children at pre-school and school age by limiting access within kindergartens, schools and tutelary-educational institutions to foodstuffs containing significant quantities of ingredients not recommended for their development [9]. It needs to be emphasized that proper diets in children and young people are very important considering the fact that excessive consumption in these groups leads to being overweight or obese caused, among others, by incorrect diets, well established in the family which means in particular an overly high calorific value for their every- 
day diet, too much animal fat and simple sugars accompanied by the limited physical activity of children and young people [10]. Typical irregularities in the diets of school children and young people are monotony, too much consumption of sugar and sweet things as well as meat and meat products, sweet carbonated drinks, fats and fast foods, combined with too little consumption of fruit and vegetables, milk and wholemeal cereal products, as well as fish [11]. In addition, it needs to be pointed out that disorders of energy balance in the body appear when certain physiological stimuli are removed from the person's everyday life e.g. when physical effort is limited [12].

The directive was issued on the basis of a statutory authorization referred to in Article 52c section 6 of the Act of Aug 25, 2006 on food and feeding safety [13], modified with the Act of Nov 28, 2014 on the modification of the Act on food and feeding safety. This Act, in Article 1 point 2, added Part IIA entitled: Foodstuffs and feeding children and young people in education system units. Under Article 52c, section 6 of the Act referred to hereinabove the minister competent for health matters will specify by means of a directive:

- the groups of foodstuffs approved for sale to children and young people in education system units;

- the requirements for foodstuffs used in the collective feeding of children and young people in education system units

- in consideration of the feeding standards for children and young people and the nutritional and health values of foodstuffs.

A violation of those provisions will be penalized with a fine or a civil sanction such as termination of contract. Under Article 52c, section 5 of the Act, if the provisions are violated, the head of a kindergarten, a school head or a head of a unit referred to in Article 2, points 3, 5, 7 of the Act of Sep 7, 1991 on the Education System (i.e. schools and other educational facilities including school youth hostels, centers for rehabilitation, centers of sociotherapy, special school-educational centers, special educational centers as well as facilities that provide care and education to students during education away from their fixed residence) are authorized to terminate, without notice, the contract with the entity responsible for the sale of foodstuffs or the provision of collective feeding to children and young people, without compensation.

Paternal responsibility for a child is the natural right of each parent. Under Article 48 of the Constitution of the Republic of Poland parents shall have the right to rear their children in accordance with their own convic- tions. This right, guaranteed in Article 48, section 1, refers to freedom of conscience and belief. Moreover, in Article 72, section 1 the Constitution ensures the protection of the rights of the child. The Constitution recognizes the supreme role of parents in the process of child education and it also covers looking after the child which involves among other things the right to make decisions about the child's diet. It needs to be said that the democratic legislator should respect the parents' right to bring up their children in accordance with their convictions i.e. also those which concern the child's diet. With the introduction of a total ban on the sales of foodstuffs containing excessive quantities of ingredients not recommended for their development, the legislator is interfering too much with the constitutional freedom to educate children in accordance with the parents' own convictions.

Another issue to be considered with respect to the introduction of the new provisions is a question about the lawfulness - in the light of Article 22 of the Constitution - of the limitation of the freedom of economic activity by banning the sales of some foodstuffs in education system units. Undoubtedly, the modification of the Act of Aug 25, 2006 on food and feeding safety introduced a limitation into the discussion upon the freedom of economic activity, which was specified in detail in the directive issued by the Minister of Health on the basis of the provisions of the Act. The legislator has the right to limit economic activity for important public reasons, which in its view includes health prevention in children and young people.

The principle of the freedom of economic activity is among the fundamental legal principles of the Polish legal order. According to the doctrine of business and administrative law it is one of the fundamental pillars of the economy [14]. However, this principle referred to in Article 20 of the Constitution is not absolute and may be limited on the basis of Article 22 of the Constitution pursuant to which a limitation of the freedom of economic activity may be imposed only by means of statute and only for important public reasons. It needs to be emphasized that the provision of Article 22 of the Constitution determines limits to state interference in economic activity. The limits are of two kinds: formal it says that the limitation upon the freedom of economic activity may be imposed "only by means of statute" and material - saying that they may be imposed "only for important public reasons" [15]. The Constitutional Tribunal in its judgment of Apr 8, 1998 [16] stated that freedom of economic activity may be subject to different limitations to a larger degree than personal rights 
and freedoms. Undoubtedly, such a value is the protection of health referred to in Article 68 of the Constitution and this is an important public reason, which justifies the limitation upon the freedom of economic activity [17]. The conditions of the introduction of limitations are set forth in Article 31, section 3 of the Constitution under which any limitation upon the exercise of constitutional freedoms and rights may be imposed only by statute, and only when necessary in a democratic state for the protection of its security or public order, or to protect the natural environment, health or public morals, or the freedoms and rights of other persons. Such limitations shall not violate the essence of freedoms and rights. The principle of proportionality referred to in Article 31, section 3 of the Constitution is an important barrier which prevents rights and freedom from being limited in an unjustified or excessive manner by the legislative authorities [18]. In conclusion, the limitation upon the freedom of economic activity in order to protect the value of health should be considered acceptable in terms of the principle of proportionality. It is also important to point out that the adopted solution is proportional to its desired purpose because it is impossible to achieve with other, less burdensome methods. Also, the opinion of the government about a draft act - filed by MPs - about the modification of the act on food and feeding safety (files no. 1127 and $1127 \mathrm{~A}$ ) is worth considering. This opinion states that in the statement of reasons for the MPs' draft act it has not been proven that the requirements of proportionality have been met and it is doubtful whether the suggested solutions are capable of guaranteeing the achievement of the desired purpose, considering the fact that children and young people willing to provide themselves with those foodstuffs subject to limitations will be able to acquire them out of units covered by bans, also during breaks between lessons [19].

The legislator assessed in legal terms two values: the freedom of economic activity and the protection of children and young people's health by introducing a ban on the sales of determined foodstuffs in a situation where, in the legislator's view, the full exercise of rights was not possible. The limitation upon the freedom of economic activity should be imposed by means of statute, which took place in the Act on food and feeding safety which in Article $52 \mathrm{c}$ indicated an authority competent to issue the directive.

On the basisi of the outlined legal status arises the question of whether the limitation upon the freedom of economic activity for businesses selling food in schools is adequate for the protected values and if it is possible to achieve the purpose set by the legislator by introducing other means aimed to limit the consumption of unhealthy foodstuffs than only by banning their sales in school shops. A possible limitation upon the freedom of economic activity of businesses conducting economic activity in schools and other educational centers needs to be considered. After the modifications enter into force, they will be the only group not to benefit from the ban but on whom the legislator imposes special duties within the scope of the distribution of so called healthy food in schools. It needs to be agreed with the legislator that the introduced bans are targeted to accomplish vital social purposes such as health protection, although the introduction of a statutory ban on the sales of certain foods is not a means necessary to achieve the purpose set by the legislator. Maybe to achieve the desired purpose, it would be sufficient to increase children and young people's awareness through education on healthy dieting or also to increase the volume of physical activity in schools. It is easy to imagine children and young people having access to foodstuffs containing significant quantities of ingredients not recommended for their development at home, after school or by going during school breaks to grocery stores located near their school-educational facilities. It seems that the achievement of the purpose, aside from the adopted legal solutions, could be guaranteed with obesity prevention programs involving, as well as proper dieting, also increased volumes of physical activity for children and young people. Some Polish cities (e.g. in Gdańsk) have introduced programs to fight against obesity in children involving examining children in determined age groups for early detection of civilization diseases.

In conclusion, it needs to be said that the limitation upon the freedom of economic activity imposed in the Act on food and feeding safety and the directive issued on the basis thereof is legally acceptable as the introduction of the solutions discussed herein above by the legislator was motivated by the need to protect children and young people's health, which is a value referred to in Article 31, section 3 of the Constitution. In the margin of this discussion, however, it needs to be added that no later than a month after the directive entered into force, buns reappeared in the list of products admissible in school shops [20] which prompts the question of whether this is only a liberalization of the adopted provisions or the begining of a return to the situation before the modifications. Let us hope that the imposed limitations will be a successful tool in the fight against obesity in children and young people and will 
lead them to learn and preserve good eating habits. However, it needs to be remembered that the solutions adopted by the legislator are not a complete remedy in the fight against obesity in children and young people.

\section{Acknowledgements}

\section{Conflict of interest statement}

The authors declare that there is no conflict of interest in the authorship or publication of contribution.

\section{Funding sources}

There are no sources of funding to declare.

\section{References}

1. Konstytucja Rzeczpospolitej Polskiej z dnia 2 kwietnia 1997 r., Dz. U. 1997 nr 78 poz. 483 ze zm.

2. Rozporządzenie z dnia 26 sierpnia 2015 roku w sprawie grup środków spożywczych przeznaczonych do sprzedaży dzieciom i młodzieży w jednostkach systemu oświaty oraz wymagań, jakie muszą spełniać środki spożywcze stosowane w ramach żywienia zbiorowego dzieci i młodzieży w tych jednostkach, Dz. U. 2015 poz. 1256

3. Orzeczenie TK z dnia 2 marca 1993 roku, sygn.. akt 9/92

4. Ustawa z dnia 28 listopada 2014 r. o zmianie ustawy o bezpieczeństwie żywności i żywienia, Dz. U. 2015 poz.

5. Rozporządzenie Prezesa Rady Ministrów z dn. 20 czerwca 2002 r. w sprawie "Zasad techniki prawodawczej", Dz. U. Nr 100, poz. 908

6. Giderewicz S. Pozorne wytyczne w przepisach upoważniających do wydania rozporządzenia. Przegląd Legislacyjny. 2013;4:51.

7. Ustawa z dnia 20 lipca 2000 r. o ogłaszaniu aktów normatywnych i niektórych innych aktów prawnych, Dz. U. 2015 poz. 1484 t.j.

8. Kaszubowski K. Komentarz do $\S 127$ rozporządzenia w sprawie "Zasad techniki prawodawczej”. In: Bąkowski T, Bielski P, Kaszubowski K, Kokoszczyński M, Stelina J, Warylewski JK, Wierczyński G. Zasady techniki prawodawczej. Komentarz do rozporządzenia, Warszawa 2003, www.lex.pl. Accessed: 1.10.2015.

9. https://legislacja.rcl.gov.pl/docs/516/12273657/122956 73/dokument180495.pdf. Accesed: 29.09.2015.

10. Jarosz M (ed.). Zasady prawidłowego żywienia dzieci i młodzieży oraz wskazówki dotyczące zdrowego stylu życia. Instytut Żywności i Żywienia, Warszawa 2008; 29.
11. Wanat G, Grochowska-Niedworok E, Kardas M, Całyniuk B. Nieprawidłowe nawyki żywieniowe i związane z nimi zagrożenie dla zdrowia wśród młodzieży gimnazjalnej. Hygeia Public Health. 2011;46(3):381.

12. Oblacińska A. Podstawy teoretyczne nadwagi i otyłości u dzieci i młodzieży. In: Oblacińska A. Wspieranie dziecka z nadwagą i otyłością w społeczności szkolnej. Warszawa 2013; 7.

13. Ustawa z dnia 25 sierpnia 2006 r. o bezpieczeństwie żywności i żywienia, Dz. U. z 2015 poz. 594.

14. Ciechanowicz-McLean J. Konstytucyjna zasada wolności gospodarczej a ochrona środowiska. Gdańskie studia prawnicze. T. XXXI. 2014; 99.

15. Byrski J, Traple E. Konstytucyjność ustawowego uregulowania maksymalnego poziomu opłaty interchange. Państwo i Prawo. 2013;6:64.

16. Wyrok Trybunału Konstytucyjnego z dnia 8 kwietnia 1998 r., sygn. K 10/97.

17. Banaszak B. Konstytucja Rzeczypospolitej Polskiej. Komentarz. Warszawa 2009; 137.

18. Ogonowski A. Konstytucyjna wolność działalności gospodarczej w orzecznictwie Trybunału Konstytucyjnego. Przegląd Prawa Konstytucyjnego. 2012;1:229-230.

19. Stanowisko Rządu wobec poselskiego projektu ustawy o zmianie ustawy o bezpieczeństwie żywności i żywienia (druki nr 1127 i 1127-A), www.senat.gov.pl. Accesses: 1.10 .2015 .

20. http://www.gazetaprawna.pl/artykuly/897124,szefowa -men-wynegocjowalam-powrot-drozdzowek-do-szkol -bede-negocjowac-kawe-i-wiecej-soli.html. Accessed: 3.10 .2015

Acceptance for editing: 2015-11-10 Acceptance for publication: 2015-12-31

Correspondence address: Monika Urbaniak Department of Medical Law 4 Rokietnicka Str., 61-806 Poznan, Poland phone: +48 616584201 email: biurozpm@ump.edu.pl 